\title{
PEMIMPIN DALAM PERSPEKTIF TOTAL QUALITY MANAJEMEN
}

\author{
Nurhadi Yasin \\ nurhadi.elfad@gmail.com \\ Sekolah Tinggi Agama Islam "Mulia Astuti” Wonogiri
}

DOI: $10.21580 /$ wa.v6i1.3100

\begin{abstract}
Educational institutions can be seen from the role of the principal as a leader (leadership). The direction of the policy taken has an impact on the performance of all elements of education. So that totality and quality will be felt by all steak holders, with orientation and a benchmark for customer satisfaction (students and student guardians). The performance pattern of school principals can be seen with four models, namely; (1) Autocratic Leader; (2) Pseudo-Democratic Leader; (3) Leader of Lasissez-Faire; (4) Democratic Leader. Of the four models, a leader is influenced by relationships, be it to the government, external stakeholders, internal stakeholders and similar institutions. The results and abilities of a leader are said to be successful if they are able to satisfy customers (students and guardians).
\end{abstract}

Keyword: leadership, student and guardians

\begin{abstract}
Abstrak
Lembaga pendidikan dapat dilihat dari peran serta kepala sekolah sebagai pemimpin (leadership). Arah kebijaka yang diambil berdampak pada kinerja seluruh elemen-elemen pendidikan. Sehingga totality dan kuality akan bisa dirasakan seluruh steak holder, dengan berorientasi dan tolok ukur pada kepuasan pelanggan (siswa dan wali murid). Pola kinerja kepala sekolah dapat dilihat dengan empat model yaitu; (1) Pemimpin Otokratis; (2) Pemimpin Pseudo-Demokratis; (3) Pemimpin Lasissez-Faire; (4) Pemimpin Demokratis. Dari empat model tersebut seorang pemimpin dipengaruhi relasi-relasi, baik itu kepada pemerintah, stake holder eksternal, stake holder internal dan lembaga-lembaga sejenis. Hasil dan kemampuan seorang pemimpin dikatakan berhasil apabila mampu memuaskan pelanggan (siswa dan wali murid).
\end{abstract}

Kata kunci: Kepemimpinan, Total Quality Managemen. 


\section{A. Pendahuluan}

Sekolah merupakan institusi paling dominan dalam proses Pendidikan. Secara makro pendidikan akan bermuara pada sekolah melalui sistem pembelajaran diseluruh kegiatan belajar mengajar, baik itu pendidikan formal maupun non formal. Dalam pendidikan kepala sekolah sangat berperan dalam menggerakkan berbagai komponen sehingga proses belajar mengajar di sekolah berjalan dengan efektif dan efisien, sesuai dengan visi dan misi sebuah lembaga pendidikan.

Peranan kepala sekolah sangat mempengaruhi quality mutu dan kemajuan sebuah institusi sekolah. Tidak hanya itu saja, kepala sekolah akan tokoh keharmonisan dalam hubungan dengan setek holder yang terkait. Baik itu berupa hubungan dengan setaf, guru, siswa dan para wali murid, pemerintah, lembaga lain, maupun stake holder eksternal seperti perusahaan-perusahaan. Dengan demikian keharmonisan dalam sekolah dan di luar sekolah akan terjaga dengan baik.

Kepala sekolah tidak hanya sebagai seorang figuran dalam lembaga pendidikan. Kepala sekolah menjadi figur sentral dengan trobosan dan kebijakan-kebijakan yang dikeluarkannya. Melalui sistem menejerial yang tersusun dengan tahapan-tahapan yang di inginkan untuk mencapai visi dan misi pendidikan.

Untuk mencapai sebuah mutu yang baik, diperlukan kepala sekolah yang bermutu tinggi artinya kepala sekolah yang mampu memberikan kepuasan kepada pelanggan. Oleh karana itu dibutuhkan total qulaiti leadership dalam kepemimpinan sekolah, dan konsisten dalam menjaga mutu yang ada di dalam sekolah.

\section{B. Pembahasan}

\section{Kepemimpinan Sekolah}

Kepemimpinan berasal dari kata pemimpin yang memuat dua hal pokok yaitu pemimpin sebagai subjek dan yang dipimpin sebagai objek. Kata pimpin mengandung arti mengarahkan, membimbing atau mengatur, menuntut, menunjukkan ataupun mempengaruhi. Secara sederhana kepemimpinan memiliki definisi kemampuan yang dimiliki seseorang untuk mempengaruhi orang lain. Hal ini mengandung makna bahwa kepemimpinan merupakan suatu kemampuan seseorang untuk mempengaruhi orang lain sehingga orang lain tunduk atau mengikuti semua keinginan seorang pemimpin. ${ }^{1}$

Kepemimpinan merupakan kemampuan yang ada dalam diri seseorang baik secara alamiah atau melalui suatu pendidikan untuk mempengaruhi orang lain baik individu maupun kelompok dalam suatu organisasi tertentu sehingga dengan sukarela anggota organisai melakukan tujuan yang hendak dicapai. ${ }^{2}$ Ada beberapa macam kekuatan atau

${ }^{1}$ Jerry H. Makawimbing, Kepemimpinan Pendidikan Yang Bermutu, (Bandung: Alfabeta Bandung, 2012), hlm. 6

${ }^{2}$ Jerry H. Makawimbing, Kepemimpinan., hlm. 9 
kekuasaan yang dimiliki pemimpin untuk menggerakkan orang lain, yaitu karna ancaman, penghargaan, otoritasa, dan bujukan. ${ }^{3}$

Di dalam lembaga pendidikan kepala sekolah merupakan pemimpin yang tertinggi sekaligus berfungsi sebagai pemberi kebijakan. Maju dan mundurnya suatu lembaga pendidikan berada ditangan kepala sekolah. Untuk itu dibutuhkan perilaku kepemimpinan yang baik dalam memimpin lembaga pendidikan, agar mutu di dalam lembaga yang ia pimpin selalu terjaga.

Seorang kepala sekolah setidak-tidaknya memiliki empat pokok prilaku yang akan membawa perubahan instansi yang dikelola, di antaranya: ${ }^{4} 1$. Memerintah, yaitu pemimpin memberitahu apa dan kapan sesuatu dikerjakan, tidak ada partisipasi dalam pengambilan keputusan. 2. Mendukung, yaitu manajer menjadi sahabat bagi pegawai dan menunjukkan minat kepada mereka. 3. Memudahkan, yaitu pemimpin memberi tahu saran dan melibatkan pegawai dalam pengambilan keputusan. 4. Orientasi prestasi, pemimpin membagi kontribusi tentang tujuan dan menunjukkan kepercayaan bahwa pegawai mampu mencapainya. Untuk itu kepala sekolah harus mampu memberi contoh keteladanan, membangkitkan semangat seluruh staf untuk mengajukan gagasan, dan mewujudkan program-program serta mendorong dan mendukung setiap setaf untuk tampil mewujudkan kemampuannya. ${ }^{5}$

Terkadang masih kedapatan kepala sekolah yang tidak memiliki prilaku yang baik sebagai seorang pemimpin di lembaga pendidikan. Hal ini dikarnakan berdasarkan cara pelaksanaannya terdapat empat tipe sebagai seorang pemimpin yaitu: ${ }^{6}$

1. Kepemimpianan otokratis,

Tipe pemimpin ini ingin memperlihatkan kekuasaannya dan ingin berkuasa. Semua yang ia rencanakan harus dipatuhi, ia merasa takut dan cemas kalau pekerjaan yang dilakukan bawahannya tidak sesuai dengan yang diharapkan. Oleh sebab itu pengawasannya selalu ketat dan menjadikan suasana di sekolah selalu tegang. Guru-guru tidak diberi kesempatan untuk mengembangkan daya kreatifitasnya dia sangat menentukan apa yang harus dikerjakan dan bagaiman cara mengerjakannya.

2. Kepemimpinan pseudo-demokratis

Seorang pemimpin yang bertipe ini sering memakai topeng, ia berpurapura memperlihatkan sifat demokratis di dalam kepemimpinannya, ia memberi hak dan kuasa kepada guru-guru untuk menetapkan dan memutuskan sesuatu,

${ }^{3}$ Nur Zazin, Gerakan Menata Mutu Pendidikan Teori Dan Aplikasi, (Yogyakarta: Ar-Ruzz Media, 2011), hlm. 196.

${ }^{4}$ Jerry H. Makawimbing, Kepemimpinan..., hlm. 21

${ }^{5}$ Nur Zazin, Gerakan..., hlm. 215.

${ }^{6}$ R. Soekarto Indrafachrudi, Bagaimana Memimpin Sekolah Yang Efektif, (Bogor: Penerbit Ghalia Indonesia, 2006), hlm. 17. 
tetapi sesungguhnya ia bekerja penuh denga perhitungan. Ia mengatur siasat agar kemauannya terwujud kelak.

3. Kepemimpinan lasissez-faire

Tipe pemimpin ini menghendaki supaya kepada bawahannya di beri banyak kebebasan. Ia berpendapat "biarlah guru-guru bekerja sesuka hatinya, berinisiatif, dan menurut kebijaksanaan sendiri”. Ia memberi kepercayaan penuh kepada bawahannya sehinga pemimpin seperti ini seringkali bekerja tanpa perencanaan.

4. Kepemimpinan demokratis.

Tipe pemimpin ini merupakan pemimpin yang sesuai dengan dewasa ini. Semua guru di sekolah bekerja untuk memcapai tujuan bersama. Semua putusan diambil melalui musyawarah dan mufakat serta harus ditaati. Pemimpin menghormati pendapat tiap-tiap guru dan memberi kesempatan kepada guru-guru untuk mengembangkan inisiatif dan daya kreatifitasnya. Pemimpin tipe ini tidak melaksanakan tugasnya sendiri, ia bersifat bijaksana di dalam pembagian pekerjaan dan tanggung jawab. Dapat dikatakan tanggung jawab berada di pundak seluruh guru-guru termasuk kepala sekolah. Sehingga di bawah kepemimpinannya guruguru bekerja secara suka rela.

Dari beberapa tipe kepemimpinan tersebut meruapakan gaya yang sangat berkaitan dengan sifat dan watak pribadi seorang pemimpin. Dalam praktiknya masih terdapat tipe yang fariatif sesuai dengan tingkat kematangan bawahan (terpimpin) yang akan dibinanya. Dan tipe-tipe tersebut akan berguna atau berjalan sesuai kebutuhan lingkungan sekolah yang di kelolanya.

Di samping itu untuk melihat secara umum, kepala sekolah yang efektif dapat dilihat dari tiga hal: pertama, komitmen terhadap visi sekolah dalam menjalankan tugas dan fungsinya. Kedua, menjadikan visi sebagai pedoman dalam mengelola dan memimpin sekolah. Ketiga, senantiasa memfokuskan kegiatan-kegiatannya terhadap pembelajaran dan kinerja guru di kelas. ${ }^{7}$ Dengan demikian kepala sekolah yang efektif akan menjaga mutu output (lulusan) dari lembaga yang ia kelola menjadi lebih baik.

\section{Konsep Total Quality Management}

Total quality management meruapak sistem manajemen yang mengangkat kualitas sebagai setrategi usaha dan berorientasi kepada kepuasan pelanggan dengan melibatkan seluruh anggota pelanggan dengan melibatkan seluruh anggota organisasi. Pelaksanaanya

${ }^{7}$ H.E. Mulyasa, Manajemen Dan Kepemimpinan Kepala Sekolah, (Jakarta: Bumi Aksara, 2013), hlm. 19. 
mencoba untuk memaksimumkan daya saing organisasi melalui perbaikan terus menerus atas produk, jasa, manusia, proses, dan lingkungannya. ${ }^{8}$

Pelaksanaan tersebut selalu kualitas yang diutamakan yang mana kualits tersebut diukur berdasarkan kepada kepuasan pelanggan. Produk-produk didesain, diproduksi, serta pelayanan diberikan untuk memenuhi keinginan pelanggan. Karna kualitas mengacu kepada segala sesuatu yang menentukan kepuasan pelanggan, suatu produk dikatakan berkualitas jika sesuai dengan keinginan pelanggan, dapat dimanfaatkan dengan baik, serta diproduksi (dihasilkan) dengan cara yang baik dan benar.'

Untuk menghasilkan produk yang berkualitas maka diperlukan perbaikan kontinu dengan tidak mengabaikan inovasi dan kreativitas atau trobosan. ${ }^{10}$ Perbaikan kontinu dapat berhasil dengan baik apabila disertai dengan usaha sumber daya manusia yang tepat. Karna factor manusia merupakan factor dimensi terpenting dalam perbaikan mutu dan produktifitas. ${ }^{11}$ Di sinilah peran utama seorang pemimpin dalam total quality management dibutuhkan. Tujuannya adalah untuk meningkatkan performa manusia, memperbaiki kualitas yang ada, meningkatkan out-put dan produktifitasnya, serta secara simultan mampu menciptakan kebanggaan kerja bagi pekerja. ${ }^{12}$

Implementasi total quality manajemen dimulai dari bawah. Dengan kata lain pelaksanaan total quality manajemen dipengaruhi kualitas pemimpin memberdayakan pegawai (bawahan). Sehingga gerakan mutu sebenarnya dimulai dari karyawan bawah. ${ }^{13}$ Untuk itu, menekankan continous improvement semi kualitas adalah tanggung jawab kepemimpinan atau komando. ${ }^{14}$

Implementasi TQM, bukanlah sebuah tugas yang hanya dikerjakan oleh seorang pemimpin saja kemudian diarahkan kepada kebawahannya. Kata "Total" menegaskan bahwa setiap seorang yang berada di dalam organisasi harus terlibat dalam upaya melakukan peningkatan secara terus menerus. ${ }^{15}$

Sebagai sebuah pendekatan, TQM mencari sebuah perubahan permanen dalam tujuan sebuah organisasi, dari tujuan kelayakan jangka pendek menuju tujuan perbaikan mutu jangka panjang. Lembaga yang mengimplementasikan TQM akan mengalami siklus perbaikan secara terus-menerus. Sehingga akan mencipatakn sebuah upaya sadar untuk hlm. 4

${ }^{8}$ Fandy Tjiptono Dan Anastasia Diana, Total Quality Management, (Yogyakarta: Andi Offset, 2002),

${ }^{9}$ Vincent Gaspersz, Total Quality Management, (Jakarta: Pt Gramedia Pustaka Utama, 2002), hlm. 5

${ }^{10}$ Soewarso Hardjosoedarmo, Bacaan Terpilih Tentang Total Quality Management, (Yogyakarta: Andi, 2002), hlm. 98

${ }^{11}$ Fandy Tjiptono dan Anastasia Diana, Total ..., hlm. 262.

${ }^{12}$ Vincent Gaspersz, Total..., hlm. 199

${ }^{13}$ Soewarso Hardjosoedarmo, Bacaan ..., hlm.34

${ }^{14}$ Soewarso Hardjosoedarmo, Bacaan., hlm. 106.

${ }^{15}$ Edward Sallis, Total Quality Management In Education Manajemen Mutu Pendidikan, Terj. Ahmad Ali Riyadi dan Fahrurrozi, (Jogjakarta: Ircisod, 2008), hlm. 74. 
menganalisis apa yang sedang dikerjakan dan merencanakan perbaikan. Unuk itu seorang manager harus mempercayai stafnya dan mendelegasikan keputusan pada tingkatantingkatan yang tepat. ${ }^{16}$

\section{Kepemimpinan Kepala Sekolah dalam Perspektif Total Quality Management (TQM)}

Kepemimpinan adalah unsur terpenting dalam total quality managemen. Pemimpin harus memiliki visi dan mampu menerjemahkan visi tersebut ke dalam kebijakan yang jelas dan tujuan yang spesifik. Mutu terpadu merupakan sebuah gairah dan pandangan hidup bagi organisasi yang menerapkannya. Untuk menerapkan mutu terpadu di dalam pendidikan dibutuhkan kepemimpinan yang unggul dalam mencapai mutu. Kriteria kepemimpinan yang bermutu membutuhkan perspektif sebagai berikut: ${ }^{17}$

1. Visi dan simbol-simbil. Kepala sekolah harus mengkomunikasikan nilai-nilai institusi kepada para setaf, para pelajar dan kepada komunitas yang lebih luas.

2. Management by walking about (manajemen dengan cara melaksanakannya), adalah gaya yang dibutuhkah bagi sebuah institusi.

3. Untuk para pelajar. Istilah ini sama dengan dekat dengan pelanggan dalam pendidikan. Ini memastikan bahwa institusi memiliki fokus yang jelas terhadap pelanggan utamanya.

4. Otonomi, eksperimentasi dan antisipasi terhadap kegagalan. Pemimpin pendidikan harus melaukan inovasi di antara staf-stafnya dan bersiap-siap mengantisipasi kegagalan yang mengiringi inovasi tersebut.

5. Menciptakan rasa kekeluargaan. Pemimpin harus menciptakan rasa kekeluargaan di antara para pelajar, orang tua, guru, dan staf institusi.

6. Ketulusan, kesabaran, semangat, intensitas, dan antusiasme. Sifat-sifat tersebut merupakan mutu personal esensial yang dibutuhkan pemimpin lembaga pendidikan.

Peran kepala sekolah adalah untuk peningkatan mutu sekolah dan pembelajaran merupakan intinya. Peningkatan mutu dapat dilaksanakan melalui peningkatan pembelajaran yang dilakakan guru, ${ }^{18}$ dengan memperhatikan input, proses, dan out-put.

Seperti dalam konsep TQM bahwa mutu dapat dilihat dari kepuasan pelanggan, sehingga kepala sekolah dituntut untuk mampu menggerakkan anggotanya agar pelanggan puas atas pelayanan sekolah yang diberikan. Kontinu sebagai proses untuk mencapai mutu yang diharapkan dimulai dari bawah. Artinya perbaikan dilakukan dari setaf yang paling

16 TQM adalah pendektan praktis, namun strategis, dalam menjalankan roda organisasi yang memfokuskan kepada pelanggan. TQM juga bias difahami sebagai filosof perbaikan tanpa henti hinggga tujuan organisasi dapat dicapai dan dengan melibatkan segenap komponen dalam organisasi tersebut. Ibid., hlm. 78-79.

${ }^{17}$ Edward Sallis, Total ..., hlm. 269-171.

${ }^{18}$ Budi Suhardian, Studi Pengembangan Kepala Sekolah Konsep Dan Aplikasi, (Jakarta: Rineka Cipta, 2012), hlm. 2 
bawah dan sesuai dengan setandar pelayanan, dari pelayanan akademik, guru, dan out-put (lulusan) yang memenuhi kebutuhan produk.

Kepala sekolah yang efektif dalam konsep TQM tidak hanya komitmen dalam visi dan misinya saja. Kemampuan untuk menanamkan visi dan misi kepada anggotanya mutlak dibutuhkan. Implementasinya tidak hanya kepala sekolah yang bekerja, semua yang terlibat dituntut untuk bekerja keras dengan mengeluarkan kemampuan yang dimiliki. Selain itu para anggotanya diberi kebebasan untuk mengembangkan kreatifitasnya sesuai dengan ketentuan-ketentaan yang telah ditetapkan. Oleh karna itu seorang pemimpin harus memberikan tanggung jawab yang tepat kepada bawahannya sesuai dengan keahliannya.

Selain itu kepemimpinan yang efektif menurut konsep manajemen kualalitas yaitu kepemimpinan yang sensitif atau peka terhadap perubahan dan melakukan pekerjaannya secara terfokus. Memimpin berarti menentukan hal-hal yang tepat untuk dikerjakan, menciptakan dinamika organisasi yang dikehendaki agar semua orang memberikan komitmen, bekerja dengan antusias untuk mewujudkan hal-hal yang telah ditetepkan. ${ }^{19}$

Seorang pemimpin ditunut sensitif dan peka terhadap perubahan kultur social, karna pada TQM juga memerlukan kultur. Kultur seluruh staf yang ada menjadi memiliki visi yang sama dengan pemimpin untuk mencapai tujuan. Karna perubahan kultur ini terkenal sulit untuk diwujudkan dan membutuhkan waktu yang cukup lama. Perubahan kultur tidak hanya bicara perubahan prilaku sikap, tetapi juga metode dalam menggerakkan lembaga. ${ }^{20}$

Keberhasilan kepemimpinan kepala sekolah dalam menjalankana TQM akan dapat dilihat secara luas oleh khalayak umum. Karana keberhasilan ini bersifat nyata, bukan dinilai dari kualitas seorang guru atau setaf-stafnya. Melainkan keberhasilan ini dinilai dari kualitas para siswa yang dimiliki. Kualitas ini mencapakup keberhasilan para siswa mempu bersaing diberbagai kompetisi yang diikuti oleh sekolah, dan juga keberhasilan para siswa mampu bersaing di perguruan tinggi. Selain itu para lulusannya mampu berasaing di ruang lingkup industri, yang artinya lulusannya secara mudah mendapatkan pekerjaan.

Mengingat lembaga pendidikan adalah institusi yang tidak berdiri sendiri, artinya lembaga yang di topang dari kepercayaan masyarakat akan perubahan dan banyak kepentingan-kepentingan yang ada di dalam maupun di luar intitusi pendidikan. Oleh karna itu pemimpin (kepala sekolah), di tuntut untuk memiliki komunikasi yang baik sehingga menghasilkan sebuah relasi yang baik pula.

\footnotetext{
${ }^{19}$ Vincent Gaspersz, Total..., hlm. 199

${ }^{20}$ Edward Sallis, Total ..., hlm. 78-79.
} 


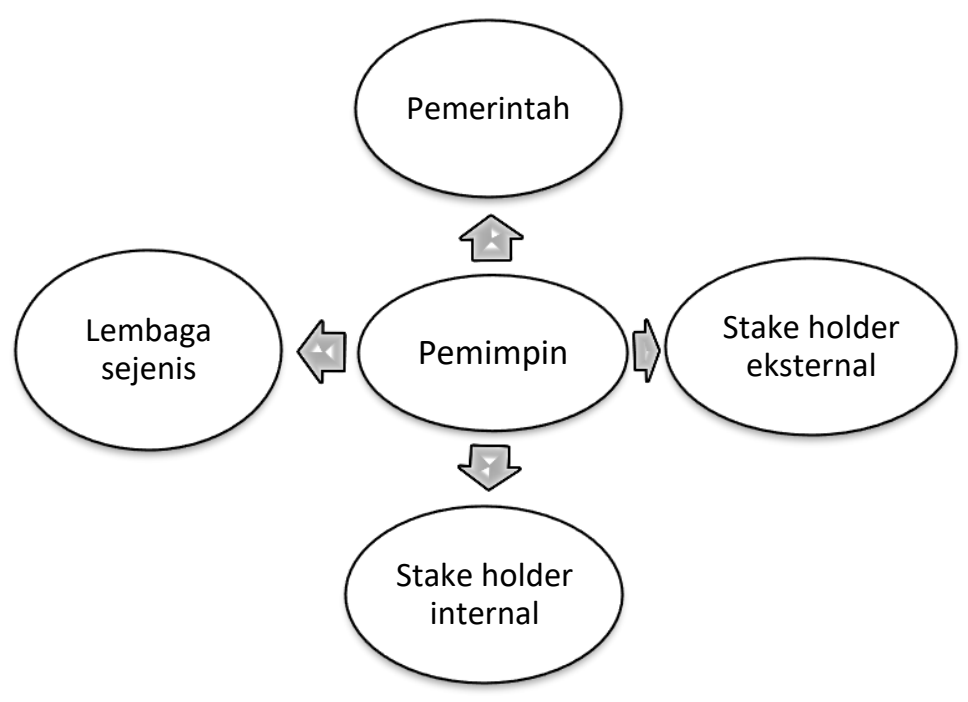

Gambar: Relasi komunikasi pemimpin

Sesuai dengan gambar di atas menunjukkan bahwa relasi kepemimpinan sekurangkurangya mencakup empat hal yang meliputi:

1. Seorang pemimpin harus mampu untuk menjalin komunikasi dengan pemerintah. Hal ini dikarnakan pendidikan merupakan salah satu harapan pemerintah untuk membangun bangsa yang lebih maju. Sehingga pemerintah ikut andil dalam perkembangan pendidikan, baik itu dalam segi kebijkan dan keuangan. Oleh karna itu seorang pemimpin dituntut untuk mampu menjalin dengam pemerintah agar lembaganya selalu mendapatkan perhatian dari pemerintah

2. Pemimpin harus mampu berkomunikasi dengan stake holder eksternal, dimana dengan adanya hubungan kepala sekolah terhadap stake holder eksternal akan memudahkan dalam pemngembangan sekolah menjadi besar dan maju. Dimana stake holder eksternal ini seperti perusahaan-perusahaan yang dekat dengan sekolah akan bisa di ajak kerja sama dan dimintai bantuan jika pemimpin mampu mambangun komuniasi dan relasi yang baik.

3. Pemimpin harus mampu bisa menjalin komunikasi terhadap lembaga-lembaga sejenis. Komunikasi ini berfungsi terhadap informasi-informasi penting dalam pengembangan sekolah sehingga jika ada sesuatu yang baru akan segera mendapat informasi terupdate dan akan mendapatkan kemudahan bantuan dalam kebutuhan-kebutuhan sekolah.

4. Pemimpin harus mampu untuk menjalin komunikasi yang baik terhadap stake holder internal. Sehingga dengan adanya komunikasi yang baik sdietiap ada permasalahan akan segera di bahas dan dicarikan solusinya. Begitu juga dalam setiap ada kebijakan dan perubahan dalam pengembangan sekolah sebagai seorang pemimpin akan mendapat dukungan penuh dari stake holder internal. 


\section{Kesimpulan}

Kepemimpianan kepala sekolah yang menerapkan TQM akan mendapat perubahan yang signifikan di dalam lembaga yang dikelolanya. Perubahan dalam lembaga ini tidak hanya dari guru-guru saja tetapi juga seluruh setaf yang terkait dari staf yang paling bawah hingga yang paling tinggi jabatannya. Sehingga pemimpin dapat dilihat dari gaya kemepemimpinannaya baik itu; Pemimpin Otokratis; Pemimpin Pseudo-Demokratis; Pemimpin Lasissez-Faire; Pemimpin Demokratis Keberhasilan kepemimpinan kepala sekolah dapat dinilai dari siswa dan out-put (lulusan) yang dididik lembaga tersebut. Dengan didukung relasi yang baik kepada pemerintah, stake holder eksternal, stake holder internal dan lembaga-lembaga sejenis.

\section{Daftar Pustaka}

Gaspersz,Vincent, Total Quality Management, Jakarta: PT Gramedia Pustaka Utama, 2002. Hardjosoedarmo, Soewarso, Bacaan Terpilih Tentang Total Quality Management, Yogyakarta: Andi, 2002.

Indrafachrudi, R. Soekarto, Bagaimana Memimpin Sekolah Yang Efektif, Bogor: Penerbit Ghalia Indonesia, 2006.

Makawimbing, Jerry H, Kepemimpinan Pendidikan Yang Bermutu, Bandung: Alfabeta Bandung, 2012.

Mulyasa, H.E, Manajemen Dan Kepemimpinan Kepala Sekolah, Jakarta: Bumi Aksara, 2013.

Sallis, Edward, Total Quality Management In Education Manajemen Mutu Pendidikan, Terj. Ahmad Ali Riyadi dan Fahrurrozi, Jogjakarta: Ircisod, 2008.

Suhardian, Budi, Studi Pengembangan Kepala Sekolah Konsep Dan Aplikasi, Jakarta: Rineka Cipta, 2012

Tjiptono, Fandy Dan Diana, Anastasia, Total Quality Management, Yogyakarta: Andi Offset, 2002.

Zazin,Nur, Gerakan Menata Mutu Pendidikan Teori Dan Aplikasinya, Jogjakarta: Ar-Ruzz Media, 2011. 